\title{
KARAKTER MANDIRI PESERTA DIDIK SD SWASTA SULUH HARAPAN SINTANG MASA PANDEMI COVID 19
}

\author{
${ }^{1}$ Daniel Dike, ${ }^{2}$ Sirilus Sirhi*, ${ }^{3}$ Risa Natalia \\ ${ }^{123}$ Program Studi Pendidikan Guru Sekolah Dasar, STKIP Persada Khatulistiwa Sintang \\ e-mail: sirilussirhi11@gmail.com
}

\begin{abstract}
The purpose of this study was to provide an overview of how the character formation of the Suluh Harapan Private Elementary School students during learning during the covid 19 pandemic. This study used a qualitative descriptive study, by examining the character formation of students, teachers, parents and school principals through interviews. , and documentation. The results of this study indicate that the strengthening of students' independent character emerges from the results of the integration of school principals in fulfilling online learning infrastructure, teacher integration in developing interesting learning, one of which is by giving craft assignments to be used as learning materials applied in both offline and bold learning, the integration of students to help increase curiosity and active learning, one of which is interesting, one of which is the handicrafts provided by the Suluh Harapan Sintang Private Elementary School teacher, as well as the integration of students' parents who help and monitor the use media during home learning.
\end{abstract}

Keywords: independent character; Covid 19; pandemic; elementary school

\begin{abstract}
ABSTRAK
Tujuan penelitian ini adalah untuk memberikan gambaran tentang bagaimana pembentukan karakter peserta didik SD Swasta Suluh Harapan selama pembelajaran di masa pandemi covid 19. Penelitian ini menggunakan kualitatif deskriptif, dengan meninjau pembentukan karakter tersebut dari peserta didik, guru, orangtua peserta didik dan kepala sekolah melalui wawancara, dan dokumentasi. Hasil penelitian ini menunjukan bahwa penguatan karakter mandiri peserta didik dimunculkan dari hasil integrasi kepala sekolah dalam pemenuhan sarana prasarana untuk pembelajaran online, adanya integrasi dari guru dalam mengembangkan pembelajaran yang menarik salah satunya dengan memberikan tugas prakarya untuk diterapkan dalam pembelajaran baik secara luring maupun daring, integrasi dari siswa untuk turut meningkatkan rasa ingin tahu dan keaktifannya dari pembelajaran yang menarik salah satunya dari prakarya yang diberikan oleh guru SD Swasta Suluh Harapan Sintang, serta integrasi dari orang tua siswa yang membantu dan memonitoring pemanfaatan media selama dilakukannya pembelajaran dirumah.
\end{abstract}

Kata kunci: karakter mandiri; Covid 19; pandemi; sekolah dasar

Cara mengutip: Dike, D., Sirhi, S. \& Natalia, R. (2021). Karakter Mandiri Peserta Didik SD Swasta Suluh Harapan Sintang Masa Pandemi Covid 19. Inteligensi: Jurnal Ilmu Pendidikan, 4(1), 51-56 


\section{PENDAHULUAN}

Pendidikan mengalami dampak dari pandemi Covid-19 ini, perubahan sistem pembelajaran daring menyebabkan proses pembelajaran harus dilaksanakan dari rumah, sesuai dengan surat Edaran Menteri Pendidikan Nasional Nomor 4 Tahun 2020, membuat peserta didik harus lebih mandiri dalam belajar (Hiryanto, 2017). Dampak ini memaksa peserta didik untuk mampu belajar secara mandiri di rumah secara online. Proses belajar mengajar memiliki selama pandemi saat ini memiliki pengaruh yang besar karena transformasi yang terjadi dari tatap muka menjadi online (Lapada et al., 2020). Salah satu sekolah yang juga merasakan dampak dari pandemi covid 19 adalah SD Swasta Suluh Harapan Sintang. Berdasarkan hasil observasi dan wawancara dengan kepala sekolah sarana dan prasarana di SD tersebut sudah cukup menunjang peserta didik dengan adanya media buku dan TIK di sekolah, namun ditinjau dari pelaksanaan pembelajaran secara online masih belum maksimal.

Pembelajaran yang dilakukan secara online harus melibatkan banyak pihak untuk membantu peserta didik tetap fokus pada pembelajaran, terutama peserta didik SD yang belum terlalu familiar dengan pembelajaran secara daring, maka guru perlu memfasilitasi pembelajaran secara online agar tetap menarik baik dengan cara menggabungkan gambar, video, audio dalam pembelajaran karena jika kemasan guru menarik maka tujuan pembelajaran dapat dicapai (Nugroho and Fatchur., 2010; Asi, 2019). Selain itu guru juga membuat program dengan pemberian tugas melalui aplikasi zoom, daring, dan tatap muka namun masih ada banyak peserta didik SD yang belum fokus pada saat pembelajaran di rumah, sehingga perlu adanya peran orangtua wali selama pelaksanaan pembelajaran di rumah (Dewi, 2020).

Peran orang tua sangat penting selama pembelajaran peserta didik di sekolah. Bunujevac and Durisic (2017) menunjukkan bahwa sebanyak 61 orang tua dari 21 sekolah berusaha untuk melakukan pemantauan, memberikan dukungan dan turut meningkatkan pemahaman tentang proses pembelajaran dengan e-learning, selain itu orang tua juga turut memiliki fasilitas dan infrastruktur yang memadai di rumah. Peserta didik umumnya dibiasakan dengan pembelajaran tatap muka, berinteraksi secara sosial dan bertemu secara fisik sehingga dibutuhkan untuk membiasakan diri bersosialisasi melalui platform online, yang dimana membutuhkan waktu untuk beradaptasi dalam meningkatkan partisipasi dalam pembelajaran interaktif online (Herliandry et al., 2020; Mustakim, 2020). Sehingga dibutuhkan interaksi kepala sekolah, guru, orangtua peserta didik untuk meningkatkan karakter mandiri peserta didik SD Swasta Suluh Harapan Sintang dalam belajar online selama pandemi covid-19.

\section{METODE PENELITIAN}

Penelitian yang dilakukan studi kepustakaan untuk menganalisis dan mengembangkan aspek teoritis dan praktis melalui kajian pustaka, wawancara dan dokumentasi (Mirzaqon \& Purwoko, 2017).

\section{HASIL DAN PEMBAHASAN}

Pemerintah Kabupaten Sintang mengeluarkan kebijakan yang tertuang dalam Surat Edaran Bupati Sintang 
Nomor: 860/ 0984/ BKPSDM dengan mengintruksikan pembelajaran peserta didik di rumah. SD Swasta Suluh Harapan Sintang sudah berusaha memenuhi setiap fasilitas baik dari segi teknologi informasi maupun jaringan internet untuk menghadapi proses pembelajaran secara daring selama masa pandemi covid-19 saat ini. Kegiatan pembelajaran di sekolah ini dilakukan secara daring dan luring dengan hanya memasukan peserta didik sebanyak 5-6 orang setiap jam, selama 1 jam dengan persetujuan orangtua peserta didik. Selama daring guru juga memanfaatkan aplikasi yang ada dimana aplikasi zoom digunakan satu kali dalam 1 minggu, selain itu juga diberikan tugas berupa prakarya yang bisa dikerjakan ole peserta didik secara langsung dirumah, kemudia di sebarkan melalui Whatshapp, untuk kemudian dikumpulkan kembali ke sekolah sesuai dengan protokol kesehatan. Dalam upaya mendukung selama peserta didik belajar mandiri dari rumah guru meminta peserta didik membuat pantun dan puisi sebagai salah satu krerativitas peserta didik selama belajar mandiri dirumah. Berdasarkan maka perlu adanya penguatan karakter mandiri pada peserta didik sekolah dasar khususnya pada saat pandemi Covid-19 di wilayah Kabupaten Sintang. Integrasi prakarya dapat membantu peserta didik untuk menemukan potensi mereka sendiri dengan berpikir di luar kotak (Autio, 2016). Rönkkö and Lepistö (2016) juga menyatakan bahwa adanya prakarya memungkinkan peserta didik untuk menyadari potensi penuh mereka serta membantu mereka untuk memperluas pikiran mereka.

Pembelajaran secara online dan pengerjaan prakarya dirumah menuntut peserta didik untuk lebih mandiri memahami materi sendiri karena tidak semua orangtua mampu mendampingi secara maksimal karena kesibukan dari setiap orangtua yang berbeda-beda, sehingga perlu penguatan karakter mandiri dari peserta didik yaitu dengan diterapkannya pembelajaran melalui aplikasi zoom, yang dilanjutkan dengan penjelasan melalui video untuk di share kembali sehingga guru dapat memantau perkembangan belajar peserta didik. Melalui pengalaman belajar yang berbeda ini, peserta didik diharapkan dapat menjadi pembelajar online yang fleksibel, sehingga peserta didik mampu menghadapi berbagai kondisi belajar dan mencari solusinya sehingga dapat meningkatkan potensinya (Bojuwon \& Ahmed, 2013). Selain itu Poulova and Simonov, (2012) menyatakan bahwa peserta didik yang belajar melalui daring cenderung memiliki kemampuan belajar yang lebih kuat secara visual dan gabungan dengan daring mampu meningkatkan kemampuan membaca dan menulis yang kuat.

Keterbukaan terhadap pengalaman belajar juga mampu mengembangkan potensi peserta didik karena mampu memperluas pengalaman belajar sehingga tingkat kemampuan meningkat dan mampy meningkatkan kemandirian peserta didik (Kopzhassarova et al., 2016), sehingga perlu adanya integrasi dari kepala sekolah dalam pemenuhan sarana prasarana untuk pembelajaran online, adanya integrasi dari guru dalam mengembangkan pembelajaran yang menarik untuk diterapkan dalam pembelajaran baik secara luring maupun daring, integrasi dari siswa untuk turut meningkatkan rasa ingin tahu dan keaktifannya dari pembelajaran yang menarik salah satunya dari prakarya yang diberikan oleh guru SD Swasta Suluh 
Harapan Sintang, serta integrasi dari orang tua siswa yang membantu dan memonitoring pemanfaatan media selama dilakukannya pembelajaran dirumah

\section{SIMPULAN}

Penguatan karakter mandiri peserta didik SD Swasta Suluh Harapan Sintang pada situasi pandemi Covid-19 merupakan hasil integrasi dari kepala sekolah, guru, peserta didik itu sendiri dan orang tua, dengan kepala sekolah yang memenuhi sarana prasana untuk pembelajaran secara daring, hingga guru yang melakukan inovasi pembelajaran hingga orangtua yang memonitoring pembelajaran dirumah maka mampu memunculkan karakter madiri yang ada di dalam diri peserta didik baik secara luring dan daring serta penggunaan prakarya sebagai tugas mandiri.

\section{DAFTAR PUSTAKA}

Asi, N. (2019). LET: Linguistics , Literature and English Teaching Journal The Analysis Of Difficulties. 9(2), 112-132.

Autio, O. (2016). Traditional craft or technology education: Development of students' technical abilities in finnish comprehensive school. International Journal of Research in Education and Science, 2(1), 75-84. https://doi.org/10.21890/ijres.05918

Bojuwon, M., \& Ahmed, S. B. (2013). The Impact of Learning Flexibility, Student Attitude and Internet Quality on E-Learning among (CELPAD) in (IIUM) Malaysia. Nternational Journal of Management Entrepreneurship and Technology (IJMET), 3(1), 1-20.

Bunujevac, M., \& Durisic, M. (2017). Parental Involvement as a Important Factor for Successful Education.
CEPS Journal, 7(3), 137-153.

Dewi, W. A. F. (2020). Dampak COVID19 terhadap Implementasi Pembelajaran Daring di Sekolah Dasar. Edukatif: Jurnal Ilmu Pendidikan, 2(1), 55-61. https://doi.org/10.31004/edukatif.v2i 1.89

Herliandry, L. D., Nurhasanah, Suban, M. E., \& Heru, K. (2020). Transformasi Media Pembelajaran Pada Masa Pandemi Covid-19. Jurnal Teknologi Pendidikan, 22(1), 65-70. http://journal.unj.ac.id/unj/index.php jitp

Hiryanto. (2017). - 65 Hiryanto. Dinamika Pendidikan, 22, 65-71.

Kopzhassarova, U., Akbayeva, G., Eskazinova, Z., Belgibayeva, G., \& Tazhikeyeva, A. (2016). Enhancement of students' independent learning through their critical thinking skills development. International Journal of Environmental and Science Education, 11(18), 11585-11592.

Lapada, A. A., Miguel, F. F., Robledo, D. A. R., \& Alam, Z. F. (2020). Teachers' Covid-19 Awareness, Distance Learning Education Experiences and Perceptions towards Institutional Readiness and Challenges. International Journal of Learning, Teaching and Educational Research, 19(6), 127-144. https://doi.org/10.26803/ijlter.19.6.8

Mirzaqon, A. T., \& Purwoko, B. (2017). Studi Kepustakaan Mengenai Landasan Teori Dan Praktik Konseling Expressive Writing Library. Jurnal BK UNESA, 1-8.

Mustakim, M. (2020). Efektivitas Pembelajaran Daring Menggunakan Media Online Selama Pandemi Covid-19 Pada Mata Pelajaran Matematika. Al Asma: Journal of Islamic Education, 2(1), 1. https://doi.org/10.24252/asma.v2i1.1 3646 
Nugroho, F. A., \& Fatchur., R. A. (2010). Pembelajaran Berbasis Multimedia. Makalah Seminar Kerja Praktek, 5, 9.

Poulova, P., \& Simonov, I. (2012). Flexible e-learning: online courses tailored to student's Needs. Proceedings of the 9th International Scientific Conference on Distance Learning in Applied Informatics (DIVAI 2012), January 2012, 251260.

http://www.klis.pf.ukf.sk/dokumenty /CALL/CALLinFLE-14Klimova.pdf

Rönkkö, M., \& Lepistö, J. (2016). The craft process developing student decision making. Techne Series: Research in Sloyd Education and Craft Science A, 23(1). 
